\title{
Monitoring of Quality in Health Care Using Indicators: Challenges and Possible Solutions
}

\author{
Mircha POLDRUgOVAC \& Tit AlBREHT
}

\begin{abstract}
A number of stakeholders identified the need to revise the national set of quality indicators. The objectives of monitoring quality indicators that were determined in 2010 for the most part were not accomplished. Key reasons include: insufficient communication between stakeholders after the indicator set was introduced, insufficient definition of human and financial resources necessary for indicators' monitoring, lack of a thorough ICT structure that could support indicators' monitoring and weak leadership for these activities. A new performance indicators' set requires a clear identification of the objectives to be pursued and consequently of the theoretical framework for the indicators. Mostly it is necessary in addition to the identification of the challenges so far, to also recognize what are the possibilities to strengthen this area in the future.
\end{abstract}

Keywords: • quality $\bullet$ health care $\bullet$ health promotion $\bullet$ efficiency $\bullet$

CorRespondence AdDress: Mircha Poldrugovac, MD, National Institute of Public Health, Trubarjeva 2, 1000 Ljubljana, Slovenia, email: mircha.poldrugovac@nijz.si. Tit Albreht, Ph.D., MD, National Institute of Public Health, Trubarjeva 2, 1000 Ljubljana, Slovenia, email: tit.albreht@nijz.si.

DOI 10.18690/24637955.10.1.53-69(2017) ISSN 2463-7955

(C) 2017 University of Maribor Press

Available at http://journals.um.si/ 
In 2010, the Ministry of Health recognised the need to expand the nationally agreed set of indicators for health care quality monitoring in Slovenia. A new set of indicators was included in the General Agreement (for the first time in Annex 2 to the General Agreement 2010 (Health Insurance Institute of Slovenia, 2011)), which was followed by the publication of the Manual on Quality Indicators (Pribaković et al. 2010) with instructions for the monitoring of the indicators. Since the beginning of the indicators monitoring in 2011, two annual reports on quality indicators were published for the year 2011 (Poldrugovac et al., 2014) and for the years 2012 and 2013 (Poldrugovac \& Simčič, 2015). The set of indicators and monitoring methodology for some of the indicators have since been amended. Nevertheless, the impact of quality monitoring using indicators in its current form is below expectations. Several stakeholders, including the Ministry of Health, have recognised the need to thoroughly revise the set of these indicators.

Manual on Quality Indicators expressed the expectation for hospitals to submit annually a written report on the achieved results of indicators monitoring (Pribaković et al., 2010). Later on, such reporting was not required by the policy makers in quality monitoring. Some hospitals have included their observations relating to the indicators in their annual reports. As of yet, there has been no formal evaluation report or other document that would attempt to comprehensively summarise the main achievements and challenges associated with the monitoring of the expanded set of indicators.

The necessity of further action in this field is supported by the listing of this task in the new Resolution on the National Health Care Plan (Ministry of Health, 2016): under Chapter 6.3.4 - Integrated management and continuous improvement of quality and safety, the Resolution lists as measure 2 "Modernisation of the set of quality indicators, monitored at the national level, including indicators of user satisfaction, and their public release." Shortcomings that gave rise to the adoption of this measure are partially disclosed in the accompanying text: "The management of quality and safety in health care in Slovenia still remains inadequately regulated and established, despite the numerous initiatives and the strategy. In particular, the agents responsible for the management of quality and safety at the national level and at the level of individual organisations (hospitals and other health care institutions) have not been clearly defined, nor has the funding been provided for key activities in the system of integrated quality and safety" (Ministry of Health, 2016). The gap between the time of the events that are being measured and the time of the release of the data has also been highlighted as problematic. Mainstream media aimed at the general public have also identified some issues in the area of quality monitoring using indicators. The subheading for one of the articles reads "data on hospital quality are sparse, unverified and published with a considerable delay; hello, Ministry?" (Rednak, 2015). In addition to the problems mentioned in 
the subheading, the article also reflects the expectation that the information would be helpful to the patients when choosing the provider to whom they would entrust their treatment.

\section{Problem description: the shortcomings of the national system of quality monitoring using indicators}

\subsection{Background}

Since the introduction of the expanded set of quality indicators in 2011, the set was amended twice; once in 2012 with Annex 1 to the General Agreement (Health Insurance Institute of Slovenia, 2012), when 4 indicators were excluded and 7 new were added, and in 2014 (Health Insurance Institute of Slovenia, 2014) with the addition of the hand hygiene indicator. A series of workshops on specific indicators took place in 2013, aimed at a discussion between health care providers who have been collecting and using the data (Poldrugovac et al, 2014). The workshops represented an opportunity for the identification of shortcomings in the methodology for the monitoring of indicators, based on which the revised instructions were issued for some indicators in April 2013.

\subsection{Objectives of quality monitoring using indicators}

Manual on Quality Indicators lists the following objectives of monitoring of quality and safety in healthcare (Pribaković et al., 2010):

»To identify more precisely the accountability relationships between all stakeholders.

To offer a background for the efficient development of quality policies at national and providers' levels.

To assist health care providers in identifying the best practices with the aim of mutual learning."

The challenge of clearly identifying all accountability relationships among stakeholders still remains. In regard to the development of professional guidelines, the Resolution on the National Health Care Plan 2016-2025 emphasises that "the institutional framework, i.e. accountability and responsibility of the main agents of this activity, should be more clearly defined ..." (Ministry of Health, 2016). The question of professional guidelines is closely linked to the development of quality indicators in each clinical area, which in turn points to the unsolved questions regarding the accountability and responsibility of institutions in this field as well. The close link between professional guidelines and quality indicators has also been identified in the Annual report on quality indicators for 2011 (Poldrugovac et al., 
2014). As is apparent from the Manual on Quality Indicators (Pribaković et al., 2010), the data is being collected and processed by several institutions: the Ministry of Health, which uses a variety of approaches to quality indicators and the so-called business performance indicators, the Medical Chamber of Slovenia, which monitors some clinical indicators, and the National Institute of Public Health in Slovenia (NIJZ), which monitors indicators that are calculated on the basis of national databases available to NIJZ. Activities in this field were supposed to be coordinated by the Steering Committee, formed within the Ministry of Health (Pribaković et al., 2010), but it has not met for several years.

The next priority objective of quality monitoring using indicators is an effective development of policies at the national and providers' levels. Common problems in the realisation of this objective are the following: 1) delayed publication of data at the national level, which does not allow for a rapid response to deviations and makes it difficult to motivate employees to introduce changes and 2) occasionally poor understanding of the methodology for indicators monitoring and the absence of oversight of data. These reasons significantly restrict the comparability of data between providers and, consequently, the usefulness of these data in guiding the design of policies for quality improvement. These challenges were also noted in the article, which primarily approached the issue from the patients' perspective (Rednak, 2015).

The third objective of quality monitoring using indicators is the identification of good practices and mutual learning. In January 2013, the first results of indicators' monitoring were presented to hospital managements. In February 2014, a conference was organised on this topic, with the emphasis on OECD indicators. In May 2015, the Section for Quality in Health Care of the Slovenian Association for Quality and Excellence hosted a meeting focused on assessing the safety in health care. None of these events focused on good practices. The main limitation is the unreliability of data and, consequentially, limited possibilities of hospital comparison. It is interesting that since the introduction of the monitoring of the expanded set of indicators, some good practices have been identified in the area of monitoring of indicators. These have been transferred from the local to the national level. For example, the University Medical Centre Ljubljana (UKC Ljubljana) and the University Clinic of Respiratory and Allergic Diseases Golnik carried out activities which lead to the monitoring of hand hygiene at national level, UKC Ljubljana played the leading role in the modernisation of the methodology for monitoring of operating room efficiency, the General Hospital Jesenice (SB Jesenice) and some other providers led the initiative for the revision of the methodology for monitoring patient falls and pressure ulcers. 


\subsection{Target groups of quality monitoring using indicators}

The Manual on Quality Indicators (Pribaković et al., 2010) states that quality monitoring using indicators is aimed at a wide range of users, which include: health care providers, payers, patients, the general public and the government. Regardless of the objectives of indicators monitoring that have been explicitly identified in the Manual, each of these target groups has their own needs. For example, the legislative or the executive branches of government may wish to verify if the regulatory framework functions properly, patients want the information that will guide them in their choice of a provider, doctors need the information about the quality of their work, so that they can then constantly improve it, the payer wants the assurance that the money they are giving foe health care services is being effectively spent, etc. (Smith et al., 2009). Determination of the target group, therefore, has significant implications for the selection of indicators that are to be monitored, as well as for the method of monitoring and the presentation of results. The objectives listed above are described as those that are "at the forefront in these initial stages" (Pribaković et al., 2010). Five years after the publication of the Manual, it might be necessary to verify their relevance.

\subsection{Conceptual framework for quality monitoring using indicators}

The question of the objectives of quality monitoring using indicators is a determining factor for the selection of the indicators themselves (Smith et al., 2009; Conry, 2012; OECD, 2010). The translation of the objectives of quality monitoring into a set of indicators represents a major challenge, which was tackled in different ways by various states and institutions. The common attribute of some of these approaches is the development of an initial conceptual framework. The set of indicators that was developed in 2010 and is listed in the Manual on quality indicators (Pribaković et al., 2010) is structured into 4 domains:

- patient centerdness,

- promotion, prevention and primary health,

- the effectiveness of health care and

- safety of patients and healthcare workers.

The structure roughly reflects the framework used in HCQI project lead by OECD (Arah et al., 2006; Carinci et al., 2015). The Manual on Quality Indicators (Pribaković et al., 2010) has not assessed this framework against the Slovenian context, nor has it described the reasons for such a choice of framework in any details. Moreover, the Manual has not linked the objectives of monitoring of quality with the framework. Another important limitation in the choice of indicators was the approach, under which the choice was made "on the basis of available data and the already accumulated experience with individual indicators" (Poldrugovac \& Simčič, 2012). Furthermore, the monitoring of business performance indicators is 
being conducted separately, outside the quality indicators framework. The Medical Chamber of Slovenia emphasised the need for a broad consensus on the set of indicators at the national level. Comments in the article that was published in the newspaper Finance (Rednak, 2015) further reveal the unsuitability of the set of indicators for the needs of patients choosing their providers.

\subsection{Method of quality monitoring using indicators}

Several issues have been identified in relation to the method of indicators' monitoring. The unreliability of various data, on which the calculation of indicators is based, was already identified in the annual report on quality indicators for 2011 (Poldrugovac et al., 2014). Several stakeholders have concluded that because of the unreliability of the data, the comparison of data between different providers is not possible (Rednak, 2015). The ambiguous methodology of indicators' monitoring was identified as one of the reasons for this unreliability. In April 2013, the Ministry of Health issued a new methodological guide for particular quality indicators in order to eliminate the identified ambiguities. There was no formal evaluation of this action. It is also worth emphasising that there was no training for providers on how to monitor quality indicators. This shortcoming has been identified in the annual report on quality indicators for 2011 as well (Poldrugovac et al., 2014).

Another important reason for the unreliability of the data is the absence of control or assessments in relation to the information on quality indicators generated by health care providers (Poldrugovac et al., 2014). NIJZ uses an automatic system of data control (Zupan et al., 2015), which does not encompass field visits or the comparison of the provided data with those in the patient medical records.

The system of preparation and publication of indicators that is used by the UK agency NICE (The National Institute for Health and Care Excellence) distinguishes two types of indicators: those that will be used for external monitoring and evaluation, for example under the so-called QOF scheme (Quality and Outcomes Framework), and those that are intended only for internal evaluation and constant improvement of quality. In the first case, the required accuracy and reliability of the data is significantly greater, since the evaluations that are based on these figures can have direct consequences, such as a reduced funding for these activities. The second type of indicators, however, only has to indicate the areas that should be given more attention, which is why they can be methodologically less rigidly determined and can be adapted to the specific circumstances of each provider (National Institute for Health and Care Excellence, n. d.). A similar attempt was made in Slovenia, where a set of clinical efficiency indicators, which are included on the national list, represents only some of the dimensions that can be calculated on the basis of data collected within the project Quality of Healthcare in Slovenia. A more extensive set of data is delivered to individual providers and is not included on the list determined in the General agreement (Health Insurance Institute of Slovenia, 2011). The data 
include a comparison with other providers in Slovenia, who are generally anonymised. The main problem with this approach was the delay with which some hospitals were sending data to the project promoters, which in turn prevented the provision of up-to-date feedback to all providers (Poldrugovac et al., 2014).

\subsection{Manner of reporting on the results of indicator monitoring}

The manner in which the data are reported to the target audience has been identified as a key element of a successful strategy for quality monitoring using indicators (Totten et al., 2012; Turnpenny \& Beadle-Brown, 2015). The Ministry of Health has opted to make the information public and has implemented this decision by issuing the annual report on quality indicators for 2011 (Poldrugovac et al., 2014). Concerns about the reliability of the data are disclosed in the report. The report also states that not all quality indicators from the General Agreement were included, the reasons for which vary: the data were not monitored, the data are not representative because the occurrences were so rare, the data are not comparable because of the unclear or misunderstood guidelines for data collection, etc. (Albreht \& Poldrugovac, 2015). The report is structured so that, in addition to the display of data, it includes a commentary, which helps the reader with the interpretation of the indicators. No separate reports for different target groups have been issued, except in the area of business indicators, which are treated separately by the Ministry of Health. Some data on business indicators can be found in the context of annual reports on the performance of public health care institutions (Ministry of Health, 2015). The authors of this article did not detect any information on the use of such data by stakeholders, and, consequently, on the direct impact of the publication of these data.

\subsection{Areas included in the set of indicators}

Even though the quality indicators were supposed to encompass the entire field of health care, the examination of the set clearly shows that the indicators relating to the quality of hospital care are prevailing. The exception is the set of indicators in the domain "promotion, prevention and primary health", where the attempt to monitor this field is being realised through indicators in the area of certain infectious diseases for which vaccination is available, indicators on hospital admissions rates attributed to diseases that can be treated at primary level, and indicators of risk factors for cardiovascular disease. It is worth emphasising that a system has been developed in recent years for quality monitoring in the so-called model practices in family medicine, which should in the near future become the organisational form for all family medicine clinics (Ministry of Health, 2016). These indicators were developed separately from the national framework, within the national project for the development of model practices in family medicine. Similarly, the national colorectal cancer screening programme (Svit) has developed a comprehensive system for quality monitoring in their own field at the national level (Novak-Mlakar, 
2013; SVIT n. d./a; SVIT n. d./b), and the framework, in this case, was also formed separately from the national framework.

Among the areas not covered by nationally agreed indicators, the Resolution on the National Health Care Plan explicitly mentions the field of dental care (Ministry of Health, 2016). In addition to dental care, the set of quality indicators provided by the Manual on Quality Indicators (Pribaković et al., 2010) or its newer version, which is determined in the General arrangement (Health Insurance Institute of Slovenia, 2013), does not include several other areas: physiotherapy, pharmacy, community nursing, laboratory activities, etc. The paucity of indicators relevant for specialist outpatient services (as opposed to hospital care) is also apparent. Perhaps the most notable is the absence of a regular monitoring of nursing homes and other types of long-term care institutions through quality indicators. The resolution has also recognised the need to develop indicators for the evaluation of health care system and listed the indicators for the monitoring thereof in the annex (Ministry of Health, 2016).

\subsection{Other factors}

Even though no evaluation of the impact of the newly introduced set of quality indicators was conducted, it is evident that many stakeholders are not satisfied with the activities carried out to date. De Vos et al. (2009), Oxman et al. (1995) and Grimshaw et al., (2001) have emphasised the importance of evaluation and consultation, as well as of other ways of actively providing feedback on the results in order to increase the impact of quality monitoring using indicators. The fact is that communication with stakeholder following the introduction of the expanded set of indicators in 2011 was relatively modest, as exemplified by the fact that the steering committee for quality indicators has not met for several years.

Peters et al. (2009) and De Vos et al. (2009) have pointed out how the insufficiency of human and financial resources for quality monitoring using indicators may negatively affect the efficiency of monitoring. After the introduction of the expanded set of quality indicators, there was no increase in the financing of providers for this purpose or in human resources in organisations at the national level that are monitoring the quality using indicators, i.e. the Ministry of Health, NJIZ and the Medical Chamber of Slovenia, or with health care providers.

In the past, providers have also stressed the importance of adequate support of information and communication technologies (ICT) in indicators monitoring. Also in this case, there was no special funding of such support for the purposes of indicators monitoring at the national level. However, it is important to note that specific funds for ICT support have been included in calculations of health care providers' costs (Health Insurance Institute of Slovenia, 2013). The level of IT support for indicators monitoring is different for each provider. The project Quality 
of Healthcare in Slovenia is an exception in that it has developed an IT solution that offers the processing of data, following their entry into the application, to all participating providers. However, even in this case, the entry of data is an additional activity, as the application is not integrated into hospital information systems, where patient medical records are stored. Another exception is the indicators that are calculated by NIJZ using the hospital discharge data, since no additional efforts are required for the collection of these data. A shortcoming of this approach lies in the fact that the original purpose of the database was not quality assessment.

Numerous shortcomings, which were described in this and in the previous chapter, indicate the weakness of governance (or stewardship) of quality indicators at the national level.

27 members of the working group have participated in the preparation of the expanded set of quality indicators in 2010, many of whom were proposed by Slovenian hospitals. The selection of indicators included indicators from the PATH project (Performance Assessment Tool for Quality Improvement in Hospitals), for which Slovenian hospitals expressed an interest, as well as indicators of the project Quality of Healthcare in Slovenia (Pribaković et al., 2010). In the latter case, the selection included those indicators and the accompanying questionnaires that were most successful in the previous decade. The project was therefore established with the expectation that it would achieve wide consensus among stakeholders. The lack of regular discussions on the set of quality indicators has also resulted in the opinion of some agents that such consensus no longer exists and that a renewal of discussions between stakeholders is essential.

\section{$3 \quad$ Possible Solutions}

The description of challenges and shortcomings of the current system of monitoring of quality indicators at the national level clearly shows that the introduction of a different set of indicators alone would not suffice to solve most of the problems. In the next part, the authors suggest two possible approaches to the revision of the set of quality indicators, which can be understood as the two extremes of a range of options. Furthermore, we have separately identified implementation challenges, i.e. the challenges that can be expected once a course of action has been decided.

\subsection{Option 1}

The main focus of the first option is to narrow the target group and the purpose of quality monitoring using indicators. Under this option, the indicators are primarily intended to evaluate the performance of providers and the performance of the health care system. They primarily serve as a tool for measuring the performance of management of health care providers on the one hand and of the health care policy makers on the other. The management of health care institutions is primarily 
accountable to the owners, i.e. mostly to the Ministry of Health, and to the payers of health care services, i.e. for the most part to the Health Insurance Institute of Slovenia. Health care policy makers, especially the Ministry of Health, but also the Health Insurance Institute of Slovenia and other institutions, are accountable to the citizens, insured persons, and the general public.

This definition of the target group and accountability relationships requires the development of a conceptual framework for monitoring of quality indicators, which is derived mainly from the objectives of health policy. The framework document regulating these objectives is the Resolution on the National Health Care Plan. The objectives of national policies are the basis for determining the objectives to be pursued by the management of health care institutions, and, consequently, for quality indicators that will be used to evaluate their performance. Since the quality indicators have to be comprehensible and manageable for the target group, while they also have to allow for a comprehensive evaluation of the effectiveness of health care, the list of indicators should be kept relatively short, and the indicators should be easily understandable.

The proposed methodology for data collection and its implementation should ensure the accuracy of the data. The achieved values of indicators should be attributable mainly to the performance of health care providers or health care policy makers. This also requires a careful monitoring of the credibility of the data, which is likely to require the examination of medical records "in the field". A relatively short list of indicators also requires a less extensive evaluation and examination and is thus more easily manageable in terms of costs.

The comments to individual indicators under this option are of secondary importance, since the indicators are supposed to be understandable and the effectiveness of performance obvious when the indicators are compared with the pursued objectives, derived from the initial framework.

This approach, similarly to the current one, anticipates a uniform national set of indicators, managed mainly by one body (committee, working group or other). The tasks of this body would be similar to those of the NICE Indicator Advisory Committee (National Institute for Health and Care Excellence, 2014). The approach would probably have to be adapted, taking into account the financial and personnel capacity of the Slovenian health care system. In this case, the establishment of clear professional guidelines for specific medical conditions at the national level would facilitate the selection of indicators in the field of clinical work, similarly to the English example.

Under this approach, the national set of indicators is not intended for comparisons between hospitals in order to identify the best practices, for internal improvements or for a precise understanding of the advantages and shortcomings in specific fields 
of medicine and other health care sciences. This means that individual subsystems in health care would form their own scheme for quality monitoring, according to their own needs, similarly to the cases of model practices in family medicine and the Svit programme. Therefore, interest groups of providers (e.g. Association of Health Institutions of Slovenia) or professional associations (e.g. individual sections of the Slovenian Medical Association) would be free to monitor the quality of performance and to develop indicators in their own field at their own discretion.

\subsection{Option 2}

The main focus of this option is a gradual introduction of indicators for the monitoring of the quality of all aspects and in all fields of health care, taking into account a comprehensive framework, which would need to be agreed first. This option preserves the broad intended use of quality monitoring using indicators, which should meet the needs of health care professionals, management of healthcare institutions, patients, policy makers at the national level, etc. The diversity of target groups, and therefore of their needs, requires an extensive set of indicators.

Especially interesting is the apparent contradiction between the patients expectation of simple, comprehensible data on quality of health services on one hand (Totten et al., 2012; Turnpenny \& Beadle-Brown, 2015), and the desire for specific data referring to their own needs and health status on the other (Turnpenny and BeadleBrown, 2015). These findings can be understood if we imagine a patient who needs shoulder surgery and has to choose the hospital where the procedure will be performed. The assessments of the quality of hospital care will likely be based on a more or less general set of indicators, such as the rates of hospital-acquired infections or mortality due to acute myocardial infarction. For a specific patient, however, the information on the success rates of the hospital, and perhaps even of particular doctors, in the performance of the needed shoulder surgery is much more relevant. In this regard, it is not surprising that in the framework of the national project on indicators in health care in Denmark the quality of hospital care is being evaluated with indicators for individual groups of patients with a specific health problem or a disease (Legido-Quigley et al., 2008). The website Hospital Compare (https://www.medicare.gov/hospitalcompare/search.html?), which includes data from US hospitals, represents an interesting solution to this dilemma, as it attempts to introduce a wide range of data, which are easily understood by the general public.

Similarly, health care professionals require quality measures that reflect their field of work, which often means monitoring of a particular medical specialty or subspecialty.

In this case, just as in Option 1, it is also necessary to establish a conceptual framework for quality monitoring using indicators. However, unlike in Option 1, such framework would not primarily derive from the objectives of health policy, 
but from a broader definition of quality in health care. An example of such definition of quality is represented by the quality domains recognised by the Institute of Medicine (Institute of Medicine Committee on Quality of Health Care in America, 2001), which were also adopted by Slovenian strategies in this area (Robida, 2006; Kiauta et al., 2010): effectiveness, safety, timeliness, efficiency, equity and patientcenterdness.

The responsibilities of individual agents differ significantly from those in Option 1. In the case of Option 2, the national central body would mainly adopt a coordinating role, intended to identify how and ensure that quality indicators from individual fields have a place within the agreed common theoretical framework. It would be necessary to establish subordinate working groups or to recognise the already existing bodies that would assume responsibility for the development of a set of quality indicators for each separate area. This area-specific list of indicators would become part of the national set of indicators, but it would also have to meet predetermined requirements for the development of indicators. Such requirements would need to be agreed and applied nationally, i.e. consistently in all areas. A similarity to the English system can be detected in Option 2 as well (National Institute for Health and Care Excellence, 2014), except that in this case, the role of the national body would be more similar to the role of NICE Guidance Executive and not to the role of NICE Indicator Advisory Committee. The role of the latter would be assumed by bodies responsible for the preparation of indicators in individual areas.

Sectoral indicators would often be closely linked to the professional doctrine, which has several important implications. The first is a possibility of a close integration with the system of professional supervision of doctors and other health care professionals. Clinical indicators could be addressed in the course of supervision with consultations. Supervisory commissions could in such cases verify the accuracy of the data while examining patient medical records, and at the same time advise the supervised persons according to the results of indicators monitoring. A similar role with regard to the monitoring of indicators could also be played by other types of supervisory commissions in the framework of administrative, financial, and even internal supervisions.

A large number of indicators, which would likely be highly technical in nature and therefore difficult to understand, would also require a more precise interpretation in comparison with indicators from Option 1. Professional associations and other stakeholders would play an important role from this perspective as well, while sectoral bodies that have developed quality indicators would be responsible for a proper interpretation of the results.

The data would have to be disclosed in different manners for different target groups. In addition to reports on the results of indicator monitoring in specific areas, the 
system for informing the patients and the public would also have to be established. As demonstrated by the US example (https://www.medicare.gov/hospitalcompare/search.html?), user-friendly web applications can be designed in addition to the reports for the patients.

The approach under this option is very demanding in all its aspects: an extensive set of indicators requires considerable human and financial resources for their development and for their regular monitoring, supervision, reporting, etc. The efforts to coordinate all described activities and to reach a consensus are likewise much more demanding when compared with the procedures under Option 1. Considering the complexity of the approach, the sectoral sets of indicators could be developed only gradually, starting with a particular field of medicine or a particular health care activity. The national coordinating body would undertake the task of determining the priority areas for the development of indicators.

\subsection{Key implementation challenges}

Past experiences with monitoring of quality indicators have been very valuable for the identification of implementation challenges. One of the repeatedly emphasised problems is the timeliness of reporting, which was also pointed out as an important principle of the statistics quality (European Statistical System Committee, 2011). Regardless of the selected option, it is necessary to ensure the quickest possible publication of results, thus affecting their usefulness and trustworthiness (Totten et al., 2012; Fung et al., 2008).

One of the possible reasons for a relatively late publication of the results of indicator monitoring is also the issue of human and financial resources needed for the performance of this work. The importance of the provision of adequate resources was recognised by several authors (De Vos et al., 2009; Peters et al., 2009).

The availability of resources also includes the question of who should provide these resources. The payer of health services or in general the bearer of the costs of health services is an institution that likely has an interest in or is responsible for monitoring the quality of the services. If these accountability relationships are not sufficiently clear, then the umbrella institution of health policy, i.e. the Ministry of Health, is the one that needs to recognise or determine which institutions or bodies are responsible for various aspects of quality monitoring using indicators. Strengthening of the policy maker's governance or leadership role is crucial for the successful implementation of actions in the area of quality monitoring using indicators.

Another major shortcoming of the current activities is the lack of a systematic approach to the evaluation of actions, either in the sense of the evaluation of the quality monitoring using indicators or in the sense of the evaluation of health 
policies as defined in strategic documents. One possible approach in the area of quality monitoring using indicators is the application of The European Statistics Code of Practice (European Statistical System Committee, 2011) as the basis for the preparation of reports on the quality of data in accordance with the recommendations of the Statistical Office of the Republic of Slovenia (Statistical Office of the RS, n. d.).

Regardless of the selected option, the feasibility of the integration of activities related to the monitoring of patient satisfaction and activities of the monitoring of business efficiency in a broader conceptual framework of the quality monitoring using indicators, which is recommended for both options, was emphasised in the problem description.

\section{$4 \quad$ Conclusions}

The key stakeholders in Slovenia have recognised the need to revise the set of quality indicators, but no comprehensive evaluation of the existing achievements has been carried out in this field. It is important that each indicator derives from the needs of the users of these indicators and therefore from the objectives of quality monitoring using indicators. Each indicator should be subjected to careful examination, verification, and adaptation to the local environment. Consequently, the process of development and selection of indicators is complex and multiphase.

On the basis of published scientific papers and other types of documents, we have identified several problems in the current system of quality monitoring using indicators in Slovenia, such as, for example, the inadequate adaptation of information to target groups, the incompatibility of the objectives of monitoring and the needs of target groups, the need to strengthen the conceptual framework for quality monitoring using indicators, the need to improve the quality of the data and the improvement of communication with providers and other target groups. In the background, these problems require the strengthening of governance and leadership for the entire field of quality monitoring using indicators, which is clearly connected to the assignment of responsibilities among the agents. Furthermore, it is necessary to provide adequate human and financial resources at all levels. In this paper, we proposed two possible approaches to the revision of the set of quality indicators. The first approach narrows the objectives of quality monitoring using indicators and is, therefore, less demanding in terms of financial and human resources than the second one, which nevertheless retains the objective of indicator monitoring for the needs of a wide range of users.

The implementation of further steps including the selection and implementation of one of the options is only meaningful if the institution responsible for health policy recognises this area as a priority and supports the implementation of further activities. 


\section{References}

Albreht, T. \& Poldrugovac, M. (2015) Doseganje kvalitativnih vidikov zdravja v Sloveniji in drugih državah EU. Presented at: Evropa, zdravstvo in mi: 18. jesensko srečanje članov društva ekonomistov v zdravstvu, October 15.-16., 2015, Radenci, Slovenija.

Arah, O. A., Westert, G. P., Hurst, J. \& Klazinga, N. S. (2006) A conceptual framework for the OECD health care quality indicators project, International Journal for Quality in Health Care, 18 (suppl 1), pp. 5-13, doi: 10.1093/intqhc/mzl024.

Carinci, F., Van Gool, K., Mainz, J., Veillard, J., Pichora, E. C., Januel, J. M. (2015) Towards actionable international comparisons of health system performance: expert revision of the OECD framework and quality indicators, International Journal for Quality in Health Care, 27(2), pp. 137-46, doi: 10.1093/intqhe/mzv004.

Conry, M. C., Humphries, N., Morgan, K., McGowan, Y., Montgomery, A., Vedhara, K. (2012) A 10 year (2000-2010) systematic review of interventions to improve quality of care in hospitals, BMC Health Services Research, 12, pp. 275, doi: 10.1186/1472-6963$12-275$.

de Vos, M., Graafmans, W., Kooistra, M., Meijboom, B., Van Der Voort, P. \& Westert, G. (2009) Using quality indicators to improve hospital care: a review of the literature, International Journal for Quality in Health Care, 21(2), pp. 119-129, doi: 10.1093/intqhe/mzn059.

European Statistical System Committee (2011) The European Statistics Code of Practice. Statistični urad RS, available at: http://www.stat.si/dokument/5179/Kodeks_zlozenka_2012.pdf (November 28, 2015).

Fung, C. H., Lim, Y. W., Mattke, S., Damberg, C. \& Shekelle, P. G. (2008) Systematic review: the evidence that publishing patient care performance data improves quality of care, Annals of Internal Medicine, 148(2), pp. 111-123.

Grimshaw, J.M., Shirran, L., Thomas, R., Mowatt, G., Fraser, C., Bero, L. (2001) Changing provider behavior: an overview of systematic reviews of interventions, Medical Care, 39(8 Suppl 2), pp- Ii2-45.

Health Insurance Institute of Slovenia (2011) Aneks 2 k Splošnemu dogovoru 2010 - Annex 2 to the General Agreement 2010, Občasnik, 1(1), pp. 25

Health Insurance Institute of Slovenia (2012) Aneks 1 k Splošnemu dogovoru 2012 - Annex 1 to the General Agreement 2012, Občasnik, (2), pp. 20.

Health Insurance Institute of Slovenia (2013) Splošni dogovor za pogodbeno leto 2013 General Agreement for 2013, Občasnik, 1(1), pp. 111.

Health Insurance Institute of Slovenia (2014) Priloga BOL II/b: Oblikovanje in financiranje programov na sekundarni in terciarni ravni, Občasnik, 2(1), pp. 52.

Institute of Medicine Committee on Quality of Health Care in America (2001) Crossing the quality chasm: a new health system for the 21st century (Washington: National Academy Press).

Kiauta, M., Poldrugovac, M., Rems, M., Robida, A. \& Simčič, B. (2010) Nacionalna strategija kakovosti in varnosti $v$ zdravstvu (National strategy of quality and safety in health care (2010-2015)) (Ljubljana: Ministry of Health).

Legido-Quigley, H., McKee, M., Nolte, E. \& Glinos, I.A (2008) Assuring the quality of health care in the European Union (Copenhagen: World Health Organization za European Observatory on Health Systems and Policies).

Ministry of Health (2015) Poročilo o poslovanju javnih zdravstvenih zavodov in JAZMP v letu 2014. Ministry of Health, available at: 
http://www.mz.gov.si/fileadmin/mz.gov.si/pageuploads/analize_poslovanja/Porocilo_o _poslovanju_JZZ_v_letu_2014_-_javno.pdf. (20.12.2015)

Ministry of Health (2016) Resolucija o nacionalnem planu zdravstvenega varstva 2016-2025 Skupaj za družbo zdravja - Predlog (Resolution on the National Health Care Plan 20162025 - Proposal) (Ljubljana: Ministry of Health).

National Institute for Health and Care Excellence (2014) Indicators Process Guide. National Institute for Health and Care Excellence, available at: http://www.nice.org.uk/media/default/standards-and-indicators/ccg-ois/indicatorsprocess-guide-2014.pdf (November 27, 2015).

National Institute for Health and Care Excellence (n.d.). Standards and indicators. National Institute for Health and Care Excellence, available at: https://www.nice.org.uk/standards-and-indicators (November 27, 2015).

Novak-Mlakar, D., Bračko, M., Maučec-Zakotnik, J., Keršič-Svetel, M. \& Metličar, T. (2013) Presejanje za raka na debelem črevesu in danki - program SVIT, Onkologija, 17(1), pp. 5.

OECD (2010) Improving Value in Health Care: Measuring Quality (Paris: OECD Health Policy Studies).

Oxman, A.D., Thomson, M.A., Davis, D.A. \& Haynes, R.B. (1995) No magic bullets: a systematic review of 102 trials of interventions to improve professional practice, Cmaj, 153(10), pp. 1423-1431.

Peters, D. H., El-Saharty, S., Siadat, B., Janovsky, K. \& Vujicic, M. (eds.) (2009) Improving health service delivery in developing countries: from evidence to action (Washington: World Bank Publications).

Poldrugovac, M. \& Simčič, B. (2012) Primerljivost kazalnikov kakovosti, ki se spremljajo na nacionalni ravni med izvajalci zdravstvenih storitev. In: Hvalič Touzery, S. (ed.) 5. mednarodna zanstvena konferenca Kakovostna zdravstvena obravnava skozi izobraževanje, raziskovanje in multiprofesionalno povezovanje - prispevek $k$ zdravju posameznika in družbe (Ljubljana: Visoka šola za zdravstveno nego Jesenice).

Poldrugovac, M. \& Simčič, B., (ed.) (2015) Kazalniki kakovosti v zdravstvu - Letno poročilo 2012 - 2013 (Ljubljana: Ministry of Health).

Poldrugovac, M., Simčič, B., Leskošek, B. \& Pajntar, M (eds.) (2014) Kazalniki kakovosti v zdravstvu - Letno poročilo 2011 (Ljubljana: Ministry of Health).

Pribaković Brinovec, R., Masten Cuznar, O., Ivanuša, M., Leskošek, B., Pajntar, M., Poldrugovac, M. (2010) Priročnik o kazalnikih kakovosti (Ljubljana: Ministry of Health).

Rednak, A. (2015) Okužbe v bolnišnicah? Nevarne, a bolniki tavajo v temi, Finance, 5 October 2015.

Robida, A. (2006) Nacionalne usmeritve za razvoj kakovosti v zdravstvu (Ljubljana: Ministry of Health).

Smith, P.C., Mossialos, E., Papanicolas, I., Leatherman, S., (eds.) (2009) Performance measurement for health system improvement: experiences, challenges and prospects (Cambridge: Cambridge University Press).

Statistical Office of the Republic of Slovenia (n. d.) Kakovost državne statistike, Statistični urad RS, available at: http://www.stat.si/statweb/glavnanavigacija/o-nas/temeljnanacela-delovanja/kakovost-statistike (November 28, 2015).

SVIT (n.d./a) Standardi kakovosti za presejalno kolonoskopsko ustanovo, SVIT, available at: http://www.program-svit.si/binary/show/1088 (November 28, 2015).

SVIT (n.d./b) Standardi kakovosti za presejalno histopatološko ustanovo. SVIT, available at: http://www.program-svit.si/binary/show/1087 (November 28, 2015). 
Totten, A.M., Wagner, J., Tiwari, A., O'Haire, C., Griffin, J. \& Walker, M. (2012) Closing the quality gap: revisiting the state of the science (vol. 5: public reporting as a quality improvement strategy), Evidence Report / Technology Assessment (Full Rep), (208.5), pp. 1-645.

Turnpenny, A. \& Beadle-Brown, J. (2015) Use of quality information in decision-making about health and social care services - a systematic review, Health and Social Care in the Community, 23(4): 349-361, doi: 10.1111/hsc.12133

Zupan, B., Zupanc, I., Zupanič, T. \& Karadža, Z. (2015) Spremljanje bolnišničnih obravnav (SBO) - Specifikacije preverjanja podatkov preko aplikacije ePrenosi, v1.8 (Ljubljana: National Institute of Public Health). 
\begin{tabular}{l|l}
70 & MEDICINE, LAW \& SOCIETY
\end{tabular} 